\title{
Comparative assessment of different methods of surgical treatment of nonbiliary necrotizing pancreatitis
}

\author{
O. V. Rozenko ${ }^{1}$, D. N. Synepupov ${ }^{1}$, A. M. Sorokin ${ }^{2}$ \\ ${ }^{1}$ Donetsk National Medical University, Mariupol, Ukraine, ${ }^{2}$ Mariupol Municipal Pancreas Center of Municipal Clinical Hospital No.1, \\ Mariupol, Ukraine
}

Over the last decade, the issue of treatment of acute necrotizing pancreatitis has been requiring special attention because of the growth of this pathology worldwide and high mortality from it, especially with extended infected types of the disease.

The aim of the research was to improve results of treatment of patients with nonbiliary necrotizing pancreatitis by optimizing of the surgical tactics, which depend on the extent of necrosis in the pancreas and peripancreatic fat.

Materials and methods. The study analyzed results of treatment of 220 patients with acute nonbiliary necrotizing pancreatitis, who were hospitalized in the clinic from 2014 to 2016. The age of the patients ranged from 18 to 80 years, including patients under the age of 50 , who accounted for $54 \%$. Comparison of qualitative features was carried out through analysis of conjugacy tables, using the $x^{2}$ Pearson criterion (Pearson Chi-square). For four-field tables (for 1 degree of freedom), the Yates's correction was used. When comparing the groups, the level of statistical significance $(P)$ was calculated. At $P<0.05$, the differences were considered statistically significant.

Results. The research argues that mortality depends not only on the extent of pancreatic necrosis, but also on the choice of method of surgical intervention. Use of puncture-draining operations under ultrasound control and lumbotomy made it possible to reduce postoperative mortality from lesser sac abscess from $6.5 \%$ to $3.9 \%$, from retroperitoneal phlegmon - from $31.6 \%$ to $15.8 \%$, and from their combination - from $60.0 \%$ to $33.3 \%$. In cases of diffuse purulent peritonitis, mortality from laparostomy combined with the programmed sanitation of the abdominal cavity was $40 \%$; it included cases when carbapenem antibiotics (imipenem/cilastatin, and meropenem) were used in the complex treatment, accounting for $33.3 \%$, and cases of implementing laparostomy, sanitation, and drainage of the abdominal cavity, making $50 \%$.

Conclusions. The more extensive use of puncture-draining operations under ultrasound control and lumbotomy, as well as laparostomy in combination with the programmed sanitation of the abdominal cavity, allowed to reduce mortality from $26.1 \%$ to $12.1 \%$.

\section{Порівняльне оцінювання різних способів хірургічного мікування небіліарного некротичного панкреатиту}

\section{О. В. Розенко, А. М. Синєпупов, А. М. Сорокін}

Мета роботи - поліпшити результати лікування хворих на небіліарний некротичний панкреатит шляхом оптимізації хірургічної тактики залежно від поширеності некрозу в підшлунковій залозі та парапанкреальній клітковині.

Матеріали та методи. Проаналізували результати лікування 220 пацієнтів із гострим небіліарним некротичним панкреатитом, які перебували на стаціонарному лікуванні у клініці з 2014 до 2016 року. Вік пацієнтів - від 18 до 80 років, 54 \% хворих були віком до 50 років. Якісні ознаки порівнювали за допомогою аналізу таблиць спряженості за допомогою критерію $X^{2}$ Пірсона (Pearson Chi-square). Для чотирипільних таблиць (для 1 ступеня свободи) використовували поправку Йейтса (Yates's correction). Порівнюючи групи, розраховували рівень статистичної значущості (p). При р <0,05 відмінності вважали статистично значущими.

Результати. Встановили, що летальність залежить не тільки від поширеності панкреонекрозу, але й від вибору способу хірургічного втручання. Так, застосування пункційно-дренуючих операцій під контролем ультразвуку та люмботомії порівняно з лапаротомією дало змогу знизити післяопераційну летальність при абсцесі сальникової сумки з 6,5 \% до 3,9 \%, при фрлегмоні заочеревинної клітковини - з 30,0 \% до 16,7 \%, а при їх поєднанні - з 60,0 \% до 33,3 \%. При розлитому гнійному перитоніті летальність при застосуванні лапаростомії в поєднанні з програмованими санаціями черевної порожнини становила 40 \%, зокрема при застосуванні в комплексному лікуванні антибіотиків із групи карбапенемів (імепенему-целастатину та меропенему) - 33,3 \%, а при застосуванні лапаротомії, санації та дренування черевної порожнини - 50 \%.

Висновки. Використання пункційно-дренуючих операцій під контролем ультразвуку та люмботомії, а також лапаростомії в поєднанні з програмованими санаціями черевної порожнини дало змогу знизити летальність порівняно 3 лапаротомією з $26,1 \%$ до $12,1 \%\left(X^{2}(1)=6,183, p=0,013\right)$.

\section{Сравнительная оценка разных способов хирургического лечения небияиарного некротического панкреатита}

\section{О. В. Розенко, А. Н. Синепупов, А. М. Сорокин}

Цель работы - улучшить результаты лечения больных с небилиарным некротическим панкреатитом путем оптимизации хирургической тактики в зависимости от распространенности некроза в поджелудочной железе и парапанкреальной клетчатке.

Key words: acute necrotizing pancreatitis, necrosis, surgical.

Zaporozhye medical journal 2018; 20 (2), 167-171 DOI 10.14739/2310-1210 2018.2.124931

E-mail: oleg.rozenko@ gmail.com, andrey-sorokin@i.ua
Кмючові слова: небіліарний некротичний панкреатит, поширеність некротичного процесу, хірургічна тактика.

Запорізький медичний журнал. - 2018. T. 20, № 2(107). C. 167-171 
Запорожский медицинский журнал. - 2018. -

T. 20, № 2(107). C. 167-171

Материалы и методы. Проанализированы результаты лечения 220 пациентов с острым небилиарным некротическим панкреатитом, которые находились на стационарном лечении в клинике с 2014 по 2016 год. Возраст пациентов - от 18 до 80 лет, 54 \% - больные в возрасте до 50 лет. Качественные признаки сравнивали с помощью анализа таблиц сопряженности с помощью критерия $\mathrm{X}^{2}$ Пирсона (Pearson Chi-square). Для четырехпольных таблиц (для 1 степени свободы) использовали поправку Йейтса (Yates's correction). При сравнении групп рассчитывали уровень статистической значимости (р). При р < 0,05 различия считали статистически значимыми.

Результаты. Установлено, что летальность зависит не только от распространенности панкреонекроза, но и от выбора способа хирургического вмешательства. Так, применение пункционно-дренирующих операций под контролем ультразвука и люмботомии по сравнению с лапаротомией позволило снизить послеоперационную летальность при абсцессе сальниковой сумки с 6,5% до 3,9%, при флегмоне забрюшинной клетчатки - с 30,0 \% до 16,7\%, а при их сочетании - с 60,0 \% до 33,3 \%. При разлитом гнойном перитоните летальность при применении лапаростомии в сочетании с программированными санациями брюшной полости составила 40 \%, в т.ч. при применении в комплексном лечении антибиотиков из группы карбапенемов (имепенема-целастатина и меропенема) - 33,3 \%, а при применении лапаротомии, санации и дренирования брюшной полости - 50 \%.

Выводы. Использование пункционно-дренирующих операций под контролем ультразвука и люмботомии, а также лапаростомии в сочетании с программированными санациями брюшной полости позволило снизить летальность по сравнению с лапаротомией с 26,1 \% до $12,1 \%\left(X^{2}(1)=6,183, p=0,013\right)$.

During the last decade, the issue of treatment of acute necrotizing pancreatitis is relevant because of the growth of this pathology worldwide and high mortality (40-60\%) from it, especially with common infected types of the disease. Surgical treatment of patients with pancreatic necrosis is based on the differentiated approach to the choice of the method and scope of surgical interventions, depending on the phase of the course of the disease, its clinical and morphological features, a patient's health, and the duration of the disease [1-3].

Various extents of necrotizing lesions of the pancreas and various topographic departments of retroperitoneal fat (purulent necrotizing peripancreatitis) determine the variety of options for surgical tactics, including the use of puncture drainage operations under ultrasound control (PDO-US), lumbotomy, and laparotomy, using various methods of drainage of retroperitoneal fat and the abdominal cavity [4-6].

In the modern concept, infection of acute necrotizing pancreatitis is a septic process that has strictly defined patterns of development, which are determined by the duration of disease, the extent of necrosis of the pancreas and retroperitoneal fat, inflammatory response from the abdominal cavity, and antibiotic prophylaxis and therapy regimens. It has been proved that, in the case of large-scale damage, infection of the necrotizing tissues of the pancreas and retroperitoneal fat occurs in the early stages of the disease (10-14 days) $[7,8]$.

In case of limited pancreatic necrosis, necrotic foci can be found in one part of the pancreas (the head, body or tail) or peripancreatic fat, and, as a rule, they do not extend to perirenal space and paracolic gutters. Focal necrosis (up to $30 \%$ ) of pancreatic parenchyma and / or peripancreatic fat does not potentially imply extensive damage and sequestration. Therefore, as a rule, the disease outcome is acute post-necrotic pseudocyst, and, when infection develops, the disease results in pancreatic abscess and/or lesser sac abscess. In case of widespread (30-50 \% of pancreatic parenchyma) and subtotal/total (more than $50 \%$ ) necrotic process, extensive sequestration of the pancreas and peripancreatic fat contributes to the formation of not only abscesses, but also phlegmon (infected peripancreatitis) of the corresponding anatomical region (left or right, pelvic) with possible complications with the abdominal cavity (purulent peritonitis, intestinal obstruction, fistula, etc.). Extensive damage to retroperitoneal fat, purulent impregnation of cell spaces like 'purulent honeycombs', the predominance of the liquid component over the tissue (necrotic tissues, sequestrants, detritus) and vice versa, require a variety of surgical treatment of retroperitoneal phlegmon (PDO-US, lumbotomy, laparotomy, or their combination) $[9,10]$.

\section{Aim}

To improve the results of treatment of patients with nonbiliary necrotizing pancreatitis by optimizing of the surgical tactics, which depend on the extent of necrosis in the pancreas and peripancreatic fat.

\section{Materials and methods}

The research analyzed results of treatment of 220 patients with nonbiliary necrotizing pancreatitis who were hospitalized at the surgery clinic of Donetsk National Medical University based on the Municipal Pancreas Center of Municipal Clinical Hospital No.1 in Mariupol from 2014 to 2016.

The age of patients ranged from 18 to 80 years, including patients under the age of 50 , who accounted for $54 \%$. There were 137 men (62.3\%) and 83 (37.7\%) women. Duration of the disease up to 24 hours was noted in $72(32.7 \%)$ patients, duration from 25 to 72 hours - in $44(20 \%)$ patients, duration of more than 72 hours - in 104 (47.3\%) patients.

The causes of nonbiliary necrotizing pancreatitis were the following: unhealthy nutrition (excessive intake of predominantly fatty foods) - in 123 (55.9\%) patients and alcohol intake (alcoholic excesses) or its surrogates - in $97(44.1 \%)$

Limited pancreatic necrosis (less than $30 \%$ necrosis of the pancreatic parenchyma) was detected in 21 (9.5\%) patients, widespread (from $30 \%$ to $50 \%$ necrosis of the pancreatic parenchyma) necrosis - in 135 (61.4\%) patients, and subtotal/total necrosis (more than $50 \%$ necrosis of the pancreatic parenchyma) - in $64(29.1 \%)$ patients.

Purulent peritonitis was diagnosed in $22(10 \%)$ patients, being caused by pancreatic abscess or lesser sac abscess revealed in the abdominal cavity in $15(68.2 \%)$ patients, by retroperitoneal phlegmon with involvement of the parietal peritoneum in inflammatory process - in $6(27.3 \%)$ 
patients, and by interstitial abscess, which was opened in the abdominal cavity - in 1 (4.5\%) patient.

Post-necrotizing infected pancreatic and peripancreatic fluid collections in the lesser sac (pancreatic abscess or lesser sac abscess, infected acute pseudocyst) and in the retroperitoneal fat (phlegmon of the retroperitoneal fat) were detected in $108(49.1 \%)$ and $76(34.5 \%)$ patients respectively, and their combination - in $14(6.4 \%)$ patients.

$39(17.7 \%)$ patients died after surgery. Sepsis and multiple organ failure were the causes of death in 36 patients, sepsis and multiple intestinal fistula - in 1 patient, arrosive bleeding from the splenic artery - in 1 patient, and pulmonary embolism - in 1 patient.

In addition to surgical methods to eliminate the focus of infection, intensive infusion-transfusion and drug therapy, antimicrobial therapy, the prevention of acute gastroduodenal ulcers and erosions, immunocorrection, nutritional support, active detoxification, and the prevention of fungal infection were used in the complex treatment of acute nonbiliary infected necrotizing pancreatitis.

Statistically obtained results were computer- processed on a personal computer Pentium IV with the programs Excel 7.0 and Statistica 6.0 by StatSoft (USA). When performing the work, the degree of reliability of the differences in the mean values in the compared groups was determined by using the Student's t- test. The effectiveness of diagnostic methods in the diagnosis was assessed by the criteria of information, sensitivity, and specificity.

Comparison of qualitative features was carried out through analysis of conjugacy tables, using the $x^{2}$ Pearson criterion (Pearson Chi-square). For four-field tables (for 1 degree of freedom), the Yates's correction was used. When comparing the groups, the level of statistical significance $(P)$ was calculated. At $P<0.05$, the differences were considered statistically significant.

\section{Results and discussion}

All patients were divided into three groups, depending on the extent of pancreatic necrosis. The first group included $21(9.5 \%)$ patients with limited necrosis of the pancreas (less than $30 \%$ necrosis of the pancreatic parenchyma), one patient died; mortality was $4.8 \%$. With diffuse purulent peritonitis as the medical indication, laparotomy, sanitation and drainage of the abdominal cavity were performed in 2 $(9.5 \%)$ patients, including opening and drainage of the lesser sac- in 1 patient; opening and drainage of retroperitoneal phlegmon - in 1 patient. One patient died after the operation.

About $14(66.7 \%)$ patients were operated for lesser sac abscess. There were no lethal outcomes. PDO-US was performed in 10 patients, laparotomy and drainage of the abscess - in 4 patients.

Retroperitoneal phlegmon was the medical indication for surgery in $5(23.8 \%)$ patients. There were no lethal outcomes. PDO-US was performed in 3 patients, including 1 patient, when retroperitoneal fat phlegmon was subsequently opened and drained by extraperitoneal access (with the help of lumbotomy) because of inadequate drainage. Laparotomy and drainage of retroperitoneal phlegmon were performed in 2 patients.

The second group included 135 (61.4\%) patients with widespread pancreatic necrosis (pancreatic parenchymal necrosis constituted from $30 \%$ to $50 \%$ ), 12 patients died; mortality accounted for $8.9 \%$.

Ten $(7.4 \%)$ patients were operated on for diffuse purulent peritonitis, including 6 patients with lesser sac abscess, which was opened and drained, and 4 patients with retroperitoneal phlegmon, which was opened and drained. Three (30\%) patients died after the operation. Laparotomy, sanitation and drainage of the abdominal cavity were performed in 6 patients; two patients died (33.3\%). The operation was completed by the imposition of laparostoma followed by the programmed sanitation of the abdominal cavity in 4 patients; one patient ( $25 \%$ ) died.

Eighty-two $(60.7 \%)$ patients were operated on for lesser sac abscess; three patients (3.7\%) died. PDO-US was performed in 63 patients, including 1 patient, who had retroperitoneal phlegmon opened and drained by extraperitoneal access because of the inefficiency of the abscess drainage and the extent of the inflammatory response to the retroperitoneal fat. Two (3.2\%) patients died after surgery. Laparotomy and the abscess drainage were performed in 19 patients; one patient died; mortality accounted for $5.3 \%$.

Thirty-nine (28.9\%) patients were operated on for lesser sac abscess; five patients (12.8\%) died. PDO-US was performed in 10 patients. Later, retroperitoneal phlegmon was opened and drained in 2 of those patients by extraperitoneal access because of inefficiency of percutaneous drainage; laparotomy, sequestrectomy, omentobursostomy were made in 1 patient because of the formation of sufficiently large sequestrations in the region of the head and body of the pancreas. Lumbotomy and drainage of retroperitoneal phlegmon were performed in 8 patients; one patient (12.5\%) died. Laparotomy, opening, and draining of retroperitoneal phlegmon were performed in 21 patients; four patients (19.1\%) died.

The combination of lesser sac abscess and retroperitoneal phlegmon was the indication for surgical intervention in 4 (3\%) patients; one patient (25\%) died. PDO-US in combination with lumbotomy, retroperitoneal drainage or laparotomy, sequestrectomy, omentobursostomy were performed in 3 patients; one patient died. Laparotomy, opening and drainage of lesser sac abscess and retroperitoneal phlegmon were performed in 1 patient.

The third group included $64(29.1 \%)$ patients with subtotal/total necrotizing pancreatitis (necrosis of more than $50 \%$ of the pancreatic parenchyma), 26 died, and mortality accounted for $40.6 \%$.

Ten $(15.6 \%)$ patients were operated on for purulent peritonitis, including 8 patients with lesser sac abscess, which was opened and drained, and 2 patients with retroperitoneal phlegmon, which was opened and drained. Six $(60 \%)$ patients died after the operation. Laparotomy, sanitation and drainage of the abdominal cavity were performed in 4 patients; three (75\%) patients died. In 6 patients, the operation was completed by the imposition of laparostoma followed by the programmed abdominal sanitation; three (50\%) patients died.

For lesser sac abscess, 12 (16.7 \%) patients were operated on; two (16.7\%) patients died. Four patients were eligible for PDO-US, including 1 patient, who subsequently underwent laparotomy, sequestrectomy, and omentobursostomy. One (25\%) patient died. Laparotomy 
and abscess drainage were performed in 8 patients; one $(12.5 \%)$ patient died.

Retroperitoneal phlegmon was the indication for surgery in $32(50 \%)$ patients, 13 (40.6\%) patients died. PDO-US was performed in 8 patients. Later, 6 patients underwent lumbotomy and retroperitoneal drainage. Four (50 \%) patients died after the operation. At the first stage, 2 patients underwent lumbotomy and retroperitoneal drainage with subsequent laparotomy, sequestrectomy and omentobursostomy. Lumbotomy and opening of retroperitoneal phlegmon were performed in 5 patients; one (20\%) patient died. Laparotomy, opening and draining of retroperitoneal phlegmon were performed in 17 patients; eight (47.1\%) patients died.

The combination of lesser sac abscess and retroperitoneal phlegmon was the indication for surgical intervention in $10(15.6 \%)$ patients; five patients (50\%) died. PDO-US in combination with lumbotomy, drainage of retroperitoneal fat or laparotomy, sequestrectomy, omentobursostomy were performed in 6 patients; two (33.3\%) patients died. Laparotomy, opening and draining of lesser sac abscess and retroperitoneal phlegmon were performed in 4 patients; three $(75 \%)$ patients died.

The analysis of the obtained data made it possible to state that the growing extent of pancreas necrosis increases the risk of development of acute infected necrotizing pancreatitis substantially. To illustrate, if, in case of infected necrotizing pancreatitis, necrosis of more than $50 \%$ of pancreatic parenchyma was observed in $29.1 \%$ of patients, in case of aseptic necrotizing pancreatitis, necrosis was detected only in $7.1 \%$. It was also noted that, in case of infected pancreatic necrosis, patients are presented beyond 72 hours after the onset of the disease more often than in case of aseptic pancreatic necrosis, accounting for $47.3 \%$ and $31.8 \%$ respectively.

Lesser sac abscess or abscesses of the pancreas and retroperitoneal phlegmon prevail in the structure of infected necrotizing pancreatitis, being found in 49.1 and $34.5 \%$ of patients respectively. Purulent peritonitis, as well as a combination of lesser sac abscess and retroperitoneal phlegmon, are much less common, being diagnosed in 10 and $6.4 \%$ of patients respectively. At the same time, the extent of pancreatic necrosis grows in line with retroperitoneal phlegmon, which is much more common now. To illustrate, patients with pancreatic necrosis, which exceeded $50 \%$, suffered from retroperitoneal phlegmon in $50 \%$ of the cases under control, from lesser sac abscess - in $18.8 \%$, from their combination - in $15.6 \%$, and from diffuse purulent peritonitis - in $15.6 \%$.

The increase of postoperative mortality grows in line with the extent of pancreatic necrosis. To illustrate, if, in total amount, mortality rate among patients with acute infected necrotizing pancreatitis made $17.7 \%$, lethality among patients with limited pancreatic necrosis accounted for $4.8 \%$; individuals with widespread pancreatic necrosis died in $8.9 \%$, and mortality among patients with subtotal/total pancreatic necrosis was equal to $40.6 \%\left(X^{2}(2)=32.659\right.$, $P<0.001)$. As it was reported, with subtotal total pancreatic necrosis, postoperative lethality occurred statistically significantly more often than with limited $\left(X^{2}(1)=7.801, P=0.005\right)$ and widespread pancreatic necrosis $\left(X^{2}(1)=26.288\right.$, $P<0.001)$. Mortality after surgery for lesser sac abscess accounted to 0 in cases of limited pancreatic necrosis, $3.7 \%$ - in cases of widespread pancreatic necrosis, $16.7 \%$ - in cases of subtotal/total necrosis. After operations for abscess of retroperitoneal phlegmon, the mortality rate constituted 0, $12.8 \%$, and $40.6 \%$ respectively. In cases of combination of the above-mentioned complications of acute pancreatitis, postoperative mortality accounted for $25 \%$ among patients with widespread pancreatic necrosis, and for $50 \%$ among patients with subtotal/total pancreatic necrosis. After surgery for diffuse purulent peritonitis, mortality rate made $30 \%$ in cases of limited pancreatic necrosis, $50 \%$ - in cases of widespread necrosis, and $60 \%$ - in cases of subtotal/total necrosis.

At the same time, the research states that the lethality depends not only on the extent of pancreatic necrosis, but also on the choice of surgical intervention method. To illustrate, in comparison with laparotomy, the use of PDO-US made it possible to reduce postoperative mortality in cases of lesser sac abscess from 6.5 to $3.9 \%$, in cases of retroperitoneal phlegmon - from 30.0 to $16.7 \%$, and when they were combined - from 60 to $33.3 \%$. In cases of diffuse purulent peritonitis, mortality from laparostomy combined with the programmed sanitation of the abdominal cavity was $40 \%$; it included cases when carbapenem antibiotics (imipenem/cilastatin, and meropenem) were used in complex treatment, accounting for $33.3 \%$, and cases of implementing laparotomy, sanitation and drainage of the abdominal cavity, making $50 \%$.

On implementing PDO-US and lumbotomy, as well as laparostomy combined with programmed abdominal sanitation, mortality from limited pancreatic necrosis was 0 ; in cases of widespread pancreatic necrosis, lethality accounted for $5.7 \%$; in cases of subtotal/total necrosis, lethality constituted $35.5 \%$; in cases when laparotomy was used, lethality was equal to $12.5 \%, 14.9 \%$, and $45.5 \%$ respectively. In general, the use of more sparing surgical interventions, as well as the step-by-step treatment of patients with infected necrotizing pancreatitis, reduced mortality compared with laparotomy from 26.1 to $12.1 \%$ $\left(X^{2}(1)=6.183, P=0.013\right)$.

\section{Conclusions}

1. The risk of development of infected necrotizing pancreatitis and, correspondingly, mortality is the higher the greater is the extent of pancreatic necrosis and the later is date after the onset of the disease when patients are admitted.

2. In case of diffuse purulent peritonitis, the operation of choice is midline laparotomy, sanitation and drainage of the abdominal cavity, including drainage of the lesser sac (in case of pancreatic abscess and/or lesser sac abscess) and retroperitoneal fat (in case of retroperitoneal phlegmon) and laparostomy followed by the programmed sanitation of the abdominal cavity.

3. In case of postnecrotic infected pancreatic and/or peripancreatic fluid collections in the pancreas or the lesser sac (pancreatic abscess or lesser sac abscess), puncture and drainage of the abscess under ultrasound control should be preferred.

4. In case of postnecrotic infected pancreatic and/ or peripancreatic fluid collections in retroperitoneal fat 
(retroperitoneal phlegmon) in the form of a fluid collection, the operation of choice is retroperitoneal drainage with several drainages under ultrasound control; in case of retroperitoneal phlegmon in the form of 'purulent honeycombs', opening and drainage by lumbar (extraperitoneal) access are to be chosen.

In cases of postnecrotic infected pancreatic and/ or peripancreatic fluid collections in retroperitoneal fat (retroperitoneal phlegmon) in the form of fluid collections, the operation of choice is drainage of retroperitoneal fat by several drainages under ultrasound control. In cases of retroperitoneal phlegmon in the form of 'purulent honeycombs', the operation of choice is opening and drainage of phlegmon by lumbar (extraperitoneal) access.

5. If limited regions of necrotizing (infected) pancreatic parenchyma (sequesters) are sufficiently large size in the body and tail of the pancreas, preference should be given to their removal from the mini-accesses, extraperitoneally (by lumbotomy). When localized in the head of the pancreas, it is advisable to perform laparotomy, sequestrectomy, omentobursostomy.

Prospects for future scientific research. A promising direction for solving the challenge of surgical treatment of necrotizing pancreatitis is further research related to the study of the criteria for early detection of necrotizing pancreatitis, objectification of its extension and development of infection that would allow for timely determination of the indications for minimally invasive interventions, reduce the number of unnecessary laparotomies, and diminish the mortality.

\section{References}

[1] Balnykov, S. I., \& Petrenko, T. F. (2010) Prognozirovanie iskhoda zabolevaniya u bol'nykh nekroticheskim pankreatitom [Prediction of the outcome in patients with necrotic pancreatitis]. Hirurgiya: Zhurnal im. N. I. Pirogova. 3, 37-40. [in Russian]

[2] Kondratenko, P. G. \& Sobolev, V. V. (2007) Khirurgicheskaya infekciya [Surgical infection]. Doneck. [in Russian].

[3] Lytras, D., Manes, K., Triantopoulou, C., Paraskeva, C., Delis, S., Avgerinos, C. \& Dervenis, C. (2008) Persistent early organ failure: defining the high-risk group of patients with severe acutepancreatitis? Pancreas, 36(3), 249-54. doi: 10.1097/MPA.0b013e31815acb2c.

[4] Nychytaylo, M. Yu., Kondratiuk, O. P., \& Snopok, Yu. V. (2009) Pankreonekroz. Profilaktyka infikuvannia ta likuvannia infektsiinykh uskladnen [Pancreonecrosis. prophylaxis and treatment of infectious complications]. Ukrainskyi zhurnal khirurhii, 4, 104-108. [in Ukrainian].

[5] Navaneethan, U., Vege, S. S., Chari, S. T. \& Baron, T. H. (2009) Minimally invasive techniques in pancreatic necrosis. Pancreas. 38(8), 867-75. doi: 10.1097/MPA.0b013e3181b3b237.

[6] Besselink, M. G. H., van Santvoort, H. C., Nieuwenhuijs, V. B., Boermeester, M. A., Bollen, T. L., Buskens, E. et al. (2006) Minimally invasive 'step-up approach' versus maximal necrosectomy in patients with acute necrotising pancreatitis (PANTER trial): design and rationale of a randomised controlled multicenter trial [ISRCTN13975868]. BMC Surgery. 6, 6. doi: 10.1186/1471-2482-6-6.

[7] Savel'ev, V. S., Filimonov, M. I., \& Burnevich, S. Z. (2008) Pankreonekrozy [Pancreatic necrosis]. Moscow. [in Russian].

[8] Oláh, A., Belágyi, T., Pótó, L., Romics, L. Jr.. \& Bengmark, S. (2007) Synbiotic control of inflammation and infection in severe acute pancreatitis: a prospective, randomized, double blind study. Hepatogastroenterology, 54(74), 590-4.

[9] Yareshko, V. G., Ryazanov, D. Yu., \& Zhivica, S. G. (2008) Lechenie pankreaticheskoj flegmony [Treatment of pancreatic phlegmon]. Klinichna khirurhiia. 4-5, 61. [in Russian].

[10] Khomiak, I. V. (2008). Malotravmatychna pozaocherevynna sanaciia vohnyshch pankreonekrozu v khirurhichnomu likuvanni hostroho nekrotychnoho pankreatytu [Low-traumatic extracorporeal sanitation of lesions of pancreatic necrosis in surgical treatment of acute necrotizing pancreatitis]. Klinichna khirurhiia. 11/12, 76-77. [in Ukrainian].

\section{Information about authors:}

Rozenko 0. V., MD, PhD, Associate Professor of the Department

of Surgery, Faculty of Residency and Postgraduate Education,

Donetsk National Medical University, Mariupol, Ukraine.

Sinepupov D. N., Assistant of the Department of Surgery, Faculty of Residency and Postgraduate Education, Donetsk National Medical University, Mariupol, Ukraine.

Sorokin A. M., Resident of the Department of Surgery, Municipal Clinical Hospital No.1, Mariupol, Ukraine.

\section{Відомості про авторів:}

Розенко О. В., канА. меА. наук, Аоцент каф. хірургії, факультет інтернатури і післяАип^омної освіти, Аонецький національний медичний університет, м. Маріуполь, Україна.

Синєпупов А. М., асистент каф. хірургії, факультет інтернатури

і післяАипломної освіти, Аонецький національний медичний університет, м. Маріуполь, Україна.

Сорокін А. М., ординатор хірургічного відАілення МК^ № 1 м. Маріуполь, Україна.

\section{Сведения об авторах:}

Розенко О. В., канА. меА. наук, Аоцент каф. хирургии, факультет интернатуры и последипломного образования, Аонецкий национальный меАицинский университет, г. Мариуполь, Украина.

Синепупов А. Н., ассистент каф. хирургии, факультет интернатуры и последипломного образования, Аонецкий национальный медицинский университет, г. Мариуполь,

Украина.

Сорокин А. М., орАинатор хирургического отАеления ГКБ № 1 , г. Мариуполь, Украина.

Conflicts of Interest: authors have no conflict of interest to declare. Конфмікт інтересів: віАсутній.

Надійшла Ао редакції / Received: 30.10.2017

Після Аоопрацювання / Revised: 13.11.2017

Прийнято Ао Аруку / Accepted: 18.12.2017 